\title{
MENINGKATKAN PROMOSI BUDAYA KESELAMATAN PASIEN DI \\ RUANG RAWAT INAP RUMAH SAKIT
}

Fara Diba Salsabila Harahap

\section{Email : salsabilaharahapfaradiba@ gmail.com}

\section{Latar Belakang}

Keselamatan pasien menjadi isu global yang paling penting saat ini dimana sekarang banyak dilaporkan tuntutan pasien atas medical error yang terjadi pada pasien. Sistem kesehatan di seluruh dunia, menghadapi tantangan dalam menangani praktik yang tidak aman, profesional layanan kesehatan yang tidak kompeten, tata pemerintahan yang buruk dalam pemberian layanan kesehatan, kesalahan dalam diagnosis dan perawatan dan ketidakpatuhan terhadap standar (Commission on Patient Safety \& Quality Assurance, 2008).

Insiden keselamatan pasien adalah peristiwa dan kondisi yang tidak disengaja yang mengakibatkan atau berpotensi menyebabkan cedera dapat dicegah pada pasien, Insiden Keselamatan Pasien (IKP) yang terdiri dari Kejadian Tidak Diharapkan (KTD), Kejadian Nyaris Cedera (KNC), Kejadian Tidak Cedera (KTC) dan Kondisi Potensial Cedera (KPC).
Perawatan rawat inap memiliki peran penting dalam pelayanan perawatan untuk observasi, diagnosis, pengobatan atau upaya perawatan kesehatan lainnya. Keselamatan pasien di rumah sakit melibatkan partisipasi dari semua petugas kesehatan, terutama perawat. Perawat memiliki peran yang paling dominan dalam mencegah terjadinya kesalahan dalam pengobatan, termasuk pelaporan insiden, mendidik diri sendiri dan orang lain. Sejalan dengan definisi keperawatan ANA 2003, yang menyatakan bahwa keperawatan adalah perlindungan, promosi, dan optimalisasi kesehatan dan kemampuan, pencegahan penyakit dan cedera, pengentasan penderitaan melalui diagnosis dan pengobatan respon manusia, dan advokasi dalam perawatan individu, keluarga, masyarakat, dan populasi. Perawat sebagai salah satu tenaga kesehatan yang mempunyai jumlah cukup dominan di rumah sakit yaitu sebesar 50 sampai $60 \%$ dari jumlah tenaga kesehatan yang ada. 
Budaya keselamatan pasien adalah pola terpadu perilaku individu dan organisasi dalam memberikan pelayanan yang aman dan bebas dari cedera. Budaya keselamatan adalah output dari individu dan kelompok terhadap nilai-nilai, sikap, kompetensi, dan pola dan kebiasaan yang mencerminkan komitmen dan gaya dan kemampuan organisasi dan manajemen keselamatan kesehatan.

Membangun budaya keselamatan pasien merupakan langkah awal dalam pengembangan keselamatan pasien. Budaya keselamatan pasien di rumah sakit merupakan bagian dari budaya organisasi, sehingga pengkajian tentang budaya organisasi diperlukan untuk menjadi panduan dalam mengembangkan keselamatan pasien.

\section{Metode}

Metode yang digunakan dalam penulisan ini yaitu menggunakan literature riview atau studi pustaka berdasarkan teks book, jurnal dan berfokus pada Meningkatkan Keselamatan Pasien di Ruang Rawat Inap Rumah Sakit . Dengan cara menganalisis, eksplorasi sumber dan kajian bebas. Adapun sumber kajian yang digunakan ialah 10 tahun terakhir.

\section{Hasil}

Keselamatan rumah sakit saat ini telah menjadi isu global. Terdapat lima komponen penting yang terkait dengan keselamatan rumah sakit yang salah satunya adalah keselamatan pasien. Keselamatan pasien dipengaruhi oleh bagaimana budaya individu dan sistem yang berjalan di dalam organisasi tersebut. Keselamatan pasien adalah suatu sistem yang membuat asuhan pasien lebih aman, meliputi asessmen risiko, identifikasi dan pengelolaan risiko pasien, pelaporan dan analisis insiden, kemampuan belajar dari insiden dan tindak lanjutnya, serta implementasi solusi untuk meminimalkan timbulnya risiko dan mencegah terjadinya cedera yang disebabkan oleh kesalahan akibat melaksanakan suatu tindakan atau tidak mengambil tindakan yang seharusnya diambil.

Persentase respon positif dari 12 dimensi budaya keselamatan pasien menunjukkan bahwa dimensi yang memiliki persentase respon positif tertinggi adalah dimensi supervisi yaitu sebesar $78 \%$, sedangkan dimensi dengan persentase respon positif terendah yaitu dimensi frekuensi pelaporan sebesar $31 \%$.

WHO menyebutkan bahwa ada beberapa faktor yang berhubungan dengan keselamatan pasien, yaitu: Organisational/managerial (budaya keselamatan, kepemimpinan, komunikasi), 
workgroup/team (struktur/proses kerja tim, pengawas), individual worker (kesadaran situasi, pengambilan keputusan, stres, kelelahan), work environment (lingkungan kerja yang berbahaya).

Henrikson menyebutkan bahwa faktor-faktor yang berkontribusi terhadap terjadinya kejadian keselamatan pasien meliputi faktor karakteristik individu, sifat dasar pekerjaan, lingkungan fisik, interaksi antara sistem dan manusia, lingkungan organisasi dan sosial, manajemen, dan lingkungan eksternal.

\section{Pembahasan}

Pada saat ini upaya untuk meningkatkan mutu pelayanan dan rneningkatkan upaya keselamatan pasien di rumah sakit sudah merupakan sebuah gerakan universal. Berbagai negara maju bahkan telah menggeser paradigma "quality" kearah paradigma baru Qualitysafety yang mengandung arti tidak hanya meningkatkan mutu pelayanan, namun yang lebih penting adalah menjaga keselamatan pasien secara konsisten dan terus menerus.

WHO menyebutkan bahwa ada beberapa faktor yang berhubungan dengan keselamatan pasien, yaitu: Organisational/managerial (budaya keselamatan, kepemimpinan, komunikasi), workgroup/team (struktur/proses kerja tim, pengawas), individual worker (kesadaran situasi, pengambilan keputusan, stres, kelelahan), work environment (lingkungan kerja yang berbahaya). Leape, Dineen, AHRQ, Depkes, Henrikson menyebutkan bahwa faktor-faktor yang berkontribusi terhadap terjadinya kejadian keselamatan pasien meliputi faktor karakteristik individu, sifat dasar pekerjaan, lingkungan fisik, interaksi antara sistem dan manusia, lingkungan organisasi dan sosial, manajemen, dan lingkungan eksternal.

Terdapat dua jenis insiden keselamatan pasien yang luas :

1. Insiden terkait dengan proses perawatan, termasuk proses administrasi, investigasi, perawatan, komunikasi dan pembayaran. Ini adalah jenis kejadian umum yang dilaporkan (berkisar antara 70\% -90\% tergantung pada penelitian).

2. Insiden terkait dengan pengetahuan atau keterampilan praktisi, termasuk diagnosis yang tidak terjawab atau tertunda, perlakuan salah dan kesalahan dalam pelaksanaan tugas.

Keselamatan pasien dan kualitas pasien adalah jantung dari penyampaian layanan kesehatan. Untuk setiap pasien, yang merawat, anggota keluarga dan profesional kesehatan, keselamatan sangat penting untuk penegakan diagnosa, tindakan 
kesehatan dan perawatan. Menurut Vincent (2008), keselamatan pasien didefinisikan sebagai penghindaran, pencegahan dan perbaikan dari hasil tindakan yang buruk atau injuri yang berasal dari proses perawatan kesehatan. Institute of Medicine (IOM) mendefinisikan keamanan sebagai "kebebasan dari kecelakaan", keselamatan pasien sebagai disiplin atau bidang penyelidikan dan tindakan belum sepenuhnya didefinisikan sampai saat ini dalam pernyataan konsensus utama organisasi yang telah mendorong keberadaannya (Hughes, 2008).

Keselamatan pasien telah diakui di banyak negara, dengan kesadaran global dipupuk oleh Aliansi Dunia untuk Keselamatan Pasien dari WHO (Emanuel, 2008). Namun tetap ada tantangan yang signifikan untuk menerapkan kebijakan dan praktik keselamatan pasien. Salah satu persyaratan mendasar untuk mengadopsi pendekatan baru adalah artikulasi yang jelas tentang premis dan manifestasinya. Tahun 2000, Institute of Medicine, Amerika Serikat dalam "TO ERR IS HUMAN, Building a Safer Health System" melaporkan bahwa dalam pelayanan pasien rawat inap di rumah sakit ada sekitar 3-16\% Kejadian Tidak Diharapkan (KTD/Adverse Event).
Keselamatan pasien adalah prioritas utama dan harus segera dilaksanakan di rumah sakit karena dapat menyebabkan cedera langsung kepada pasien, juga terkait dengan kualitas dan citra rumah sakit serta standar pelayanan yang harus dipenuhi oleh rumah sakit itu terkait dengan versi 2012 dari standar akreditasi mengacu pada Joint Commission International (JCI).

Perlu pemahaman dan memiliki pengetahuan bagi perawat tentang peningkatan efektifitas sistem ataupun halhal yang berkaitan dengan resiko-resiko yang akan terjadi dalam sistem yang meliputi pengetahuan, keterampilan dan sikap untuk dapat mempromosikan keselamatan yang akan menghasilkan kualitas perawatan yang tinggi dalam pelayanan (Finkelman \& Kenner, 2009). Penerapan budaya keselamatan pasien akan mendeteksi kesalahan yang akan dan telah terjadi (Fujita et al., 2013; Hamdan \& Saleem, 2013; Kaufman \& McCaughan, 2013). Budaya KP tersebut akan meningkatkan kesadaran untuk mencegah error dan melaporkan jika ada kesalahan (Jeffs, Law, \& Baker, 2007).

Peran perawat dalam mengimplementasikan asuhan keperawatan dan mewujudkan keselamatan pasien di rumah sakit dapat dirumuskan sebagai berikut, perawat harus 
mematuhi standar layanan dan SOP yang telah ditetapkan, menerapkan prisip etik dalam meberikan asuhan keperawatan, memberikan pendidikan kepada pasien dan keluarga pasien tentang asuhan keperawatan yang sedang dijalankan, selalu bekerjasama dengan tim kesehatan yang lainnya dalam memberikan asuhan keperawatan, menerapkan komunikasi yang baik terhadap sejawat, pasien dan keluarga, selalu proaktif dan peka dalam menyelesaikan kejadian atau insiden yang berkaitan dengan keselamatan pasien, mendokumentasikan segala bentuk kegiatan yang ada hubungannya dengan asuhan keperawatan yang dilakukan kepada pasein.

\section{Budaya keselamatan pasien} merupakan suatu hal yang pentingkarena membangun budaya keselamatan pasien merupakan suatu cara untukmembangun program keselamatan pasien secara keseluruhan, karena apabila kita lebih fokus pada budaya keselamatan pasien maka akan lebih menghasilkan hasil keselamatan yang lebih apabila dibandingkan hanya menfokuskan pada programnya saja. Teori Reason menyatakan bahwa insiden keselamatan pasien disebabkan oleh dua faktor, kesalahan laten dan kesalahan aktif. Kesalahan laten terkait dengan insiden keselamatan pasien meliputi lingkungan eksternal, manajemen, lingkungan sosial atau organisasi, lingkungan fisik, interaksi antara manusia dan sistem. Kunci pencegahan cedera dalam pelayanan keperawatan adalah identifikasi risiko. Hal ini sangat tergantung pada budaya kepercayaan, kejujuran, integritas, dan keterbukaan berkomunikasi dalam sistem asuhan keperawatan.

\section{Penutup}

Keselamatan pasien menjadi isu global yang paling penting saat ini dimana sekarang banyak dilaporkan tuntutan pasien atas medical error yang terjadi pada pasien. Insiden keselamatan pasien adalah peristiwa dan kondisi yang tidak disengaja yang mengakibatkan atau berpotensi menyebabkan cedera dapat dicegah pada pasien, Insiden Keselamatan Pasien (IKP) yang terdiri dari Kejadian Tidak Diharapkan (KTD), Kejadian Nyaris Cedera (KNC), Kejadian Tidak Cedera (KTC) dan Kondisi Potensial Cedera (KPC). Budaya keselamatan pasien adalah pola terpadu perilaku individu dan organisasi dalam memberikan pelayanan yang aman dan bebas dari cedera. Membangun budaya keselamatan pasien merupakan langkah awal dalam pengembangan keselamatan pasien. Perawatan rawat inap memiliki peran penting dalam pelayanan perawatan untuk 
observasi, diagnosis, pengobatan atau upaya perawatan kesehatan lainnya.

\section{Daftar Pustaka}

Herawati.Y.T.

(2015).Budaya

Keselamatan Pasien di Ruang Rawat Inap Rumah Sakit X Kabupaten Jember ( Patient Safety Culture Inpatient In The Hospital X District Jember) . Jurnal IKESMA Volume 11 Nomor 1.: 52-60.

Iriviranty A.(2015). Analisis Budaya Organisasi dan Budaya Keselamatan Pasien di RSIA Budi Kemuliaan Tahun 2014.Jurnal Administrasi Rumah Sakit.Vol 1(3).Hal. 196-206.

Mandriani E , Hardisman, Yett H. (2019). Analisis Dimensi Budaya Keselamatan Pasien Oleh Petugas Kesehatan di RSUD dr Rasidin Padang Tahun 2018. Jurnal Kesehatan Andalas., 8(1) : 131-137.

Pagala, I. Shaluhiyah Z . Widjasena B. (2017). Perilaku Kepatuhan Perawat Melaksanakan SOP Terhadap Kejadian Keselamatan Pasien di Rumah Sakit X Kendari . Jurnal Promosi Kesehatan Indonesia, 12 (1) : 138-149.

Simamora, R. H., \& Fathi, A, (2019). The Influence Of Training Handover Based SBAR Communication For
Improving Patients Safety, Indian journal of public health research \& development, 10(9), 1280-1285.

Suci.W P. (2018). Peningkatan Budaya Keselamatan Pasien Melalui Pemberdayaan Champion Keselamatan Pasien. JKH : 2(2).

Syam N.S. (2017). Implementasi Budaya Keselamatan Pasien oleh Perawat di Rumah Sakit Ibnu Sina Makassar.Jurnal Fakultas Kesehatan Makassar.Vol. 11(2).Hal.169-174.

Tutiany. Lindawati. Krisanti. Paula S. (2017) . Manajemen Keselamatan Pasien. Badan PPSDM Kesehatan : 297 halaman.

Yarnita.Y. (2018 ). Analisis Hubungan Sikap Perawat Dengan Budaya Keselamatan Pasien di Ruang Rawat Inap RSUD Arifin Achmad Provinsi Riau. Jurnal Photon 8 ( 2) : 81-85.

Yasmi Y. Hasbullah T.(2018).FaktorFaktor Yang Berhubungan dengan Budaya Keselamatan Pasien di Rumah Sakit Karya Bhakti Pratiwi Bogor Tahun 2015. Journal Administrasi Rumah sakit.Vol. 4(2).Hal 98-109.

Yusuf,M. (2017). Penerapan Patient Safety di Ruang Rawat Inap Rumah Sakit Umum Daerah DR.Zainoel Abidin. Jurnal Ilmu Keperawatan, 5 ( 1 ). 
